\title{
State of the plate: Assessing present and future contribution of fisheries and aquaculture to Hawai'i's food security
}

Lida T. Teneva ${ }^{a,}{ }^{*}$, Eva Schemmel ${ }^{a}$, John N. Kittinger ${ }^{a, b, c}$

a Conservation International, Center for Oceans, 7192 Kalaniana'ole Hwy, Ste. G-230, Honolulu, HI 96825, USA

${ }^{b}$ Arizona State University, Center for Biodiversity Outcomes, Julie Ann Wrigley Global Institute of Sustainability, Life Sciences Center, A Wing 451 E Tyler Mall, Room 208, Tempe, AZ 85281, USA

${ }^{\mathrm{C}}$ Conservation International, Betty and Gordon Moore Center for Science, Arlington, VA 22202, USA

* Correspondence to: 2410 S Street, Apt 3, Sacramento, CA 95816, USA. E-mail address: lida.teneva@gmail.com (L.T. Teneva).

This is the accepted manuscript of a paper published in Marine Policy. The final version may be accessed at https://doi.org/10.1016/j.marpol.2018.04.025.

\section{Abstract}

Seafood provides the most important source of protein on the planet, and millions in coastal communities depend on this sector for nutrition, livelihoods, and cultural values. Despite seafood's important role, in many locations the contributions of fisheries and aquaculture to local food security have not been accurately assessed. An overview is provided of current and future contributions of seafood to food security in Hawai'i through metrics using a supply chain approach from hook-to-plate, encompassing production and consumption. Hawai'i's local seafood production is nearly 21,000 metric tons per year, with $\sim 90 \%$ sourced from pelagic fisheries, and $6 \%$ from reef fisheries. Seafood is a bright spot in the overall Hawai'i food system, providing a relatively higher degree of self-sufficiency than other food sources. Annual local production of seafood in Hawai' $i$ is estimated at $20,424,243 \pm 1,958,488 \mathrm{~kg}(\mu \pm$ SD). Accounting for imports and exports, the total locally available seafood $(32,450,820 \mathrm{~kg} \pm 1,571,905 \mathrm{~kg})$ accounts for about $134 \pm 6.5$ million meals available every year. Wild-capture fisheries (pelagic and nearshore) in Hawai' $\mathrm{i}$ are modeled to be able to meet $45 \%$ or less of the growing seafood demand in Hawai'i by 2040, compared to an estimated $55 \%$ in 2015 . A projected $20 \%$ increase in total seafood demand by 2040 would exceed current average annual local production by up to $37 \%$. Improvement in sustainable fisheries, aquaculture, and innovations in value and supply chains are critical if Hawai' $i$ is to improve its seafood security and the food provisioning functions of ocean and coastal environments. 


\section{Introduction}

Human activities in coastal environments have resulted in significant impacts to ocean health and diminishing returns to society from these ecosystems [1-4]. Critical ocean ecosystem services such as fisheries, coastal protection, and cultural values are essential to the health and wellbeing of coastal communities and are diminishing globally $[5,6]$. Fisheries contribute $20 \%$ of the protein for 3.1 billion people's diets and $17 \%$ of global protein consumed, representing a crucial contribution to global food security [1,7-11]. The ocean is the biggest source of protein for humanity, and aligning food self-sufficiency goals in seafood with natural resource management goals can lead to effectively achieving Sustainable Development Goals (SDGs). Yet, this benefit to humanity from the oceans is tenuous because about $31 \%$ of all assessed fish stocks are overfished, and $58 \%$ are fished at full capacity [11].

Nowhere are coastal fisheries more important for seafood self-sufficiency than in the developing economies and communities of Pacific Island Countries and Territories. Many coastal fisheries in this region have significant capacity gaps in management, threatening the food and livelihood security that these fisheries provide to communities [7,12-14]. In most areas, rural coastal communities are witnessing increasing fishing effort and resource depletion as they become integrated into market systems that supply growing demand in urban centers [7]. These changes are coincident with dietary shifts to processed, imported foods and erosion of cultural fishing practices [15], which result in declines in fishing pressure in some regions [16]. Across the region, local stressors such as overfishing and pollution as well as global threats such as climate change are causing major impacts to coastal ecosystems [17-23], with consequences for food security in resource-dependent communities [7,10,24,25].

In Hawai' $i$, public interest in food security and the potential for self-sufficiency has increased in recent decades as locally sourced food and seafood has declined in its contribution to meeting local food demand. Attitudes in Hawai'i towards food security and food self-sufficiency have been summarized in the past as "local production for local consumption, under local control" [26]. Seafood is an integral part of society - a reflection of the Hawaiian archipelago's unique geography, culture, and history. Seafood comprises $>20 \%$ of all animal protein consumed in Hawai' $i$ - the highest of any other food category - and is a particularly important source of protein for low-income households in Hawai'i (<\$35,000 USD per year) [27]. Fishing and providing local seafood towards household food self-sufficiency and security is of high cultural and nutritional value in Hawai' $i$, underscoring the need for sustainable management [28]. Demand for seafood is expected to increase in the future due to projected population growth. However, Hawai'i's nearshore fisheries are threatened by local stressors such as overfishing, land-based pollution and invasive species, as well as global threats such as climate change, which are impacting the food security benefits of these food systems $[7,8,10,24]$,

Despite the importance of coastal fisheries to Hawai'i's economy, communities, and culture, little is understood about the functional role these fisheries play in food security for the archipelago. Recent work has shown that small-scale coral reef fisheries in Hawai'i provide largescale benefits to the economy, food security, and cultural practices, contributing millions 
of meals per year to households [28]. But little is known about the full scope of all fisheries' contributions to food security and food self-sufficiency in Hawai' $i$.

Food security is broadly defined as including 'physical, social, and economic access to safe and nutritious food that meets the local needs [29]. Food self-sufficiency refers to a region's ability to produce all the food necessary to satisfy the local demand and need for that food [26,30,31]. For seafood, this requires us to understand the total production from fisheries and aquaculture, the total demand for seafood, dependency on local versus imported seafood sources, and how these trends are expected to change in the future under projected demand growth and climate change.

A clearer picture of the current state and the critical factors that influence seafood security and seafood self-sufficiency can help inform a range of interventions to improve management of local fisheries and seafood supply chains. This includes informing market-based interventions and policy and governance reform to protect the role of local fisheries and aquaculture production in food security, the economy, and community resilience [7].

Here, based upon recent evaluations of total nearshore fisheries production and a value chain assessment for Hawai'i [28], the current and future state of seafood security are evaluated. The objective is to (1) refine metrics for seafood production's role in food self-sufficiency at a local/regional scale, using the Hawaiian Archipelago as a case study, (2) offer novel metrics that forecast future seafood consumption and potential changes in capacity for seafood selfsufficiency by 2040 , (3) identify economic challenges that a growing gap could pose for people in Hawai'i, and (4) propose pathways to sustainable production in coastal fisheries. The overarching goal is to inform conservation practitioners, community-level resource stewards, fisheries managers, fishers, seafood consumers, and decision-makers with practical information that would help enhance food security and sustainable production - in Hawai' $i$ and beyond.

\section{Methods}

\subsection{Overview}

A supply chain approach is used here in the examination of the current status of seafood security and seafood self-sufficiency, using the primary supply chain components of production, distribution, and consumption (Fig. 1) [28,32-34]. Each of the three primary components of seafood security is dependent upon the proper functioning of its corresponding link in the supply chain. Specifically, physical availability of seafood is dependent upon sufficient production, economic access to seafood is dependent upon fair and equitable distribution, and shifts in demand and socioeconomic and cultural factors affect seafood consumption.

To assess the status of seafood security, a set of indicators, focusing on production and consumption functions was developed. Here, 9 indicators in total were defined, 5 in production and 4 in consumption, based on reviewing food policy and food self-sufficiency research 
relevant to Hawai'i $[11,26,31]$, as well as available research in our target geography and sector [35-37] (Table 1). The 4 forward-looking consumption indicators are novel and developed here for Hawai' i based on criteria considered by the authors to be important for the future, including 1 ) increased total seafood demand, 2) increasing fish protein gap between what can be locally produced and what is needed to meet the local seafood demand; 3 ) increasing seafood prices linked to preferences and price elasticity in a growing population, 4) changes in household expenses. These factors are critical to illuminate if Hawai' $i$ is to preserve large-scale food, income, and livelihood benefits from local fisheries.

Distribution pathways for food are crucial for access and food security, and production modes for seafood can vary due to a number of complex factors, with impacts on benefits from seafood production systems [38,39]. Due to the complexity of distribution pathways, and the lack of detailed data on seafood distribution networks in Hawai'i, this study focuses the indicators on the key production and consumption aspects of seafood systems.

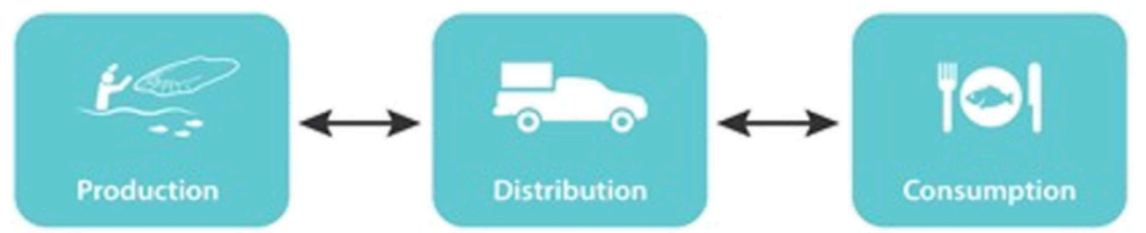

Fig. 1. Seafood supply systems consist of production, distribution, and consumption processes, all of which affect seafood security (modified after Grafeld et al. [28]).

Table 1. Seafood security indicators ( $\mathrm{PI}=$ Production Indicator; $\mathrm{Cl}=$ Consumption Indicator).

\begin{tabular}{|c|c|c|}
\hline Indicator & Equation & Inputs \\
\hline PI\#1: Local Production (LP) & $\mathrm{LP}=\mathrm{Comm}+\mathrm{NComm}+\mathrm{AQ}$ & $\begin{array}{l}\text { Comm = commercial primary fisheries, including nearshore coastal, bottom, reef, and } \\
\text { pelagic fisheries } \\
\text { NComm = non-commercial primary fisheries } \\
\mathrm{AQ}=\text { finfish and shellfish aquaculture }\end{array}$ \\
\hline $\begin{array}{l}\text { PI\#2: Total Locally Available Seafood } \\
\text { (TLAS) }\end{array}$ & TLAS $=\mathrm{LP}+\mathrm{M}-\mathrm{E}$ & $\begin{array}{l}\mathrm{M}=\text { foreign imports, foreign imports through U.S. transshipments, continental U.S. imports, } \\
\text { nearshore fish imports from commercial dealers as well as in checked luggage in incoming } \\
\text { air travel } \\
\mathrm{E}=\text { =xports }\end{array}$ \\
\hline PI\#3: Seafood Self-Sufficiency Ratio (SSR) & $\mathrm{SSR}=\mathrm{LP} /(\mathrm{LP}+\mathrm{M}-\mathrm{E})$ & Methodology from [26] \\
\hline $\begin{array}{l}\text { PI\#4: Seafood Import Dependency Ratio } \\
\text { (IDR) }\end{array}$ & $\mathrm{IDR}=\mathrm{M} /(\mathrm{LP}+\mathrm{M}-\mathrm{E})$ & Dethodology from [26] \\
\hline $\begin{array}{l}\text { PI\#5: Seafood Provided per Capita by } \\
\text { TLAS (SPPC) per year }\end{array}$ & $\begin{array}{l}\text { SPPC }=\text { TLAS }^{*} 0.7 / \text { RPMPP } \\
=\text { SPPC } / 0.17\end{array}$ & $\begin{array}{l}\text { RP }=\text { Resident Population } \\
\text { MPP }=\text { Meals Per Person (per year) } \\
\text { Methodology from }[28,35]\end{array}$ \\
\hline $\begin{array}{l}\text { CI\#1: Future Seafood Demand (FSD) } \\
\text { Lower and Upper Bounds }\end{array}$ & $\begin{array}{l}\text { Lower Bound: } \\
\mathrm{FSD}_{\mathrm{LB}}=\mathrm{RP}_{\mathrm{I}} * 12.9 \\
\text { Upper Bound: } \\
\mathrm{FSD}_{\mathrm{UB}}=\mathrm{RP}_{\mathrm{I}} * \mathrm{SPPC}\end{array}$ & $\begin{array}{l}\text { RP } \mathrm{RP}_{\mathrm{I}} \text { is the modeled resident population for } 2015-2040 \text {, available from State of Hawai' } \mathrm{i} \text { data. } \\
12.9 \mathrm{~kg} \text { is the seafood per capita computed by Geslani et al. [35] } \\
\mathrm{SPPC}=16.7 \mathrm{~kg} \text { is the annual average seafood per capita potential consumption and assumed } \\
\text { demand for } 2009-2013 \text { (this study). } \\
\text { Methodology: this study }\end{array}$ \\
\hline CI\#2: Future Production Gap (FPG) & FPGI = FSDI - (LP-E) & $\begin{array}{l}\text { The FPG changes every year in the model, dependent on the FSD, and it has a lower and } \\
\text { upper bound as a function of FSD. } \\
\text { Methodology: this study }\end{array}$ \\
\hline $\begin{array}{l}\text { CI\#3: Future Seafood Market Price } \\
\text { (FSMP) }\end{array}$ & $\mathrm{FSMP}=\mathrm{TRV} / \mathrm{TCH}$ & $\begin{array}{l}\text { TRV }=\text { Total Retail Value of all the commercial fisheries catch, annual average } 2007-2011 \\
\text { TCH }=\text { Total Commercial Harvest for all commercial fisheries catch, annual average } \\
2007-2011 \\
\text { Methodology from [37] }\end{array}$ \\
\hline $\begin{array}{l}\text { CI\#4: Future Household Seafood Budget } \\
\text { (FHSB) }\end{array}$ & $\mathrm{FHSB}=\mathrm{FSMP} * \mathrm{SPPC} * 4$ & Methodology: this study \\
\hline
\end{tabular}




\subsection{Indicators}

Indicators for are summarized in Table 1 and data sources and calculations are further described below.

\subsubsection{Production indicators (PI)}

\subsubsection{Local production (PI\#1)}

Local Production refers to the total seafood that is produced in Hawai'i. Existing data were synthesized to estimate the total seafood production from the primary fisheries, including nearshore coastal, bottom, reef, and pelagic fisheries, as well as aquaculture. These represent the primary fisheries in the archipelago and together with aquaculture, comprise the major production sources for local seafood. Due to data limitations, this research purposefully excludes other smaller fisheries such as periodic seasonal fisheries, or fisheries for specific products limited to certain geographies, noting that such fisheries can represent significant sources of food as well as cultural practices in communities [40]. On-land aquaculture including freshwater aquaculture, is also excluded, restricting the focus here to marine finfish, invertebrates, seaweed and other marine products harvested from wild-capture fisheries or produced in aquaculture in coastal aquatic environments. The aquaculture production estimates come from the latest available data, 2008-2011 [41]. Aquaculture reports were not available for recent years; therefore, the authors in this study made the assumption that average annual finfish and shellfish annual aquaculture production is similar in recent years to averages from 2008 to 2011.

Commercial bottomfish production is an average of 2006-2010 Hawai'i Department of Land and Natural Resources - Division of aquatic Resources, available through NOAA's Pacific Islands Fisheries Science Center [42]. The non-commercial bottomfish production is an average of 2006-2010 data, from two model scenarios of the Deep 7 complex (Lehi, Silverjaw Snapper, Aphareus rutilans; Ehu, Squirrelfish Snapper, Etelis carbunculus; Onaga, Longtail Snapper, Etelis coruscans; Opakapaka, Pink Snapper, Pristipomoides filamentosus; Kalekale, Von Siebold's Snapper, Pristipomoides sieboldii; Gindai, Brigham's Snapper, Pristipomoides zonatus; Hapu'upu'u, Hawaiian Seabass, Hyporthodus quemus) [37]. Non-commercial pelagic catch data (including albacore, yellowfin tuna, big-eye tuna, giant trevally, blue marlin, striped marlin, skipjack tuna) for 2009-2013 were collected by the NOAA Marine Recreational Information Program [43]. Non-commercial reef production estimates come from recent analyses [28].

\subsubsection{Total locally available seafood (PI\#2).}

Total Locally Available Seafood is calculated as all seafood available to Hawai'i. This includes locally produced seafood PI\#1) as an annual average for the 2009-2013 period, and also includes imports (foreign imports, foreign imports through U.S. transshipments, continental U.S. imports, nearshore fish imports from commercial dealers as well as in checked luggage in incoming air travel) $[28,35,44]$.

\subsubsection{Seafood self-sufficiency ratio (PI\#3).}


The Seafood Self-Sufficiency Ratio (SSR) estimates the extent to which Local Production meets total seafood demand. To calculate this, the total Local Production amount (inclusive of seafood that is actually exported) is used; therefore, this is a theoretical metric which tracks the total possible contributions of Local Production to meeting local demand, if all Local Production was to stay in Hawai'i and contribute to self-sufficiency. Therefore, SSR is calculated as the amount of Local Production divided by the sum of Local Production and all imports (foreign imports, foreign imports through U.S. transshipments, continental U.S. imports, nearshore fish imports from commercial dealers as well as in checked luggage in incoming air travel), minus exports and re-exports in seafood from Hawai' $i$ and exports to the continental U.S. [35], in accordance with Hawaiian land-based food production studies [26].

\subsubsection{Seafood import dependency ratio (PI\#4).}

The Seafood Import Dependency Ratio (IDR) estimates the contribution of seafood imports to Total Locally Available Seafood, and is thus calculated as the sum of all imports (foreign imports, foreign imports through US transshipments, continental US imports, nearshore fish imports from commercial dealers as well as airline travelers), divided by the sum of Local Production, imports, minus exports of seafood from Hawai'i.

\subsubsection{Seafood provided per capita by total locally available seafood (PI\#5).}

The Seafood Provided per Capita (SPPC) is the theoretical provision of seafood per person in Hawai'i per year, and this is equated to the local demand by Hawai'i residents. While the authors acknowledge that tourist demand does add to Hawaii residents' demand for local seafood, the analysis presented in this paper is constrained to assessing the role of local seafood in local Hawaii residents' food security and do not assess or predict the future pressure of tourist demand on Hawaii's natural resources. The latter topic certainly merits further study and would be informative for natural resource management purposes.

To calculate the seafood provided per capita, both total weight of per capita seafood potentially available per year and also potential total number of meals were determined. The Total Locally Available Seafood annual estimate averaged over the 2009-2013 period is used, with the assumption that $70 \%$ of the catch is edible weight (excluding bones, heads, etc., [28]). Once the edible weight is calculated in this way, a $0.17 \mathrm{~kg}$ ( 6 ounce) per seafood meal conversion factor was used, following previously described approaches [45], to define the total number of meals potentially provided by our estimate of Total Locally Available Seafood. The number of meals per person is calculated by dividing the total number of meals by the resident population estimate [46], and the meals per person are then converted to potential seafood per capita provision. This estimate, then, is used as a proxy for seafood demand per capita.

\subsubsection{Consumption indicators}

\subsubsection{Future seafood demand (Cl\#1).}

Future Seafood Demand (FSD) for all of Hawai'i residents for 2018-2040 was estimated by using parameters from a population growth model [47], and multiplying by the per capita seafood demand [11], with a lower bound for per capita seafood demand of $16.5 \mathrm{~kg}$ from this study (as 
estimated in PI\#5 above) and upper bound of $16.7 \mathrm{~kg}$ [35]. The average of those two estimates is provided with an envelope with lower and upper bound. In the next section of the methods, the authors made the assumption seafood demand per capita into the future remains within these bounds estimated here.

\subsubsection{Future production gap (Cl\#2).}

The Future Production Gap (FPG) is essentially the Local Production annual average for 2009213 (minus exports), assuming this amount remains constant through 2040, subtracted from the Future Seafood Demand for the whole population, for the period 2018-2040.

\subsubsection{Future seafood market price (Cl\#3).}

Future Seafood Market Price (FSMP) per kilogram for average consumer calculated by dividing annual total retail value of local commercial landings by annual total number of kilograms of local commercial landings for 2007-2011 [37], and applying an annual assumed price increase of 1\% [48] to project annual average retail price of seafood per kilogram from 2011 to 2040. The price per kilogram of seafood the average consumer in Hawai'i pays is reported from [35] and was calculated by dividing the annual total retail value of local landings by the annual total of the local landings, each year for 2007-2011. Real fish prices are projected to rise by $1 \%$ in real terms in the next decade [48]; however, it is important to note that this may vary based on exogenous factors (such as changes in the cost of fuel), changes in fisheries status, or market dynamics. Additionally, our approach subsumes species- and commodity-specific changes in favor of a coarse level average for the entire sector.

\subsubsection{Future household seafood expenditures (CI\#4).}

Future Household Seafood Expenditures (FHSB) estimates the annual household food budget expenditures. To calculate this, the authors use information on Future Seafood Market Price (FSMP, CI\#3), Seafood Provided per Capita by TLAS (16.5 kg, PI\#5 above), and projected resident monthly food budgets for 2004-2014 [49]. Future Seafood Market Prices (FSMP) for 2018-2040 were multiplied by Seafood Provided per Capita by TLAS (SPC, PI\#5) to estimate the

total cost per year per person. Resident food budgets were corrected for inflation using a linear regression model to project monthly and annual per capita food budgets up to 2040 . A projected annual growth of $1.7 \%$ was estimated and applied to the projected per capita total food budget for 2015-2040 [48]. Resident food budget data from the State of Hawai'i are collected with the assumption of 4-person households. The projected seafood budget from 2011 to 2040 is then calculated as a percentage of the total annual food budgets for households in Hawai'i for a household size of 4, to estimate the fraction of seafood costs in household budgets in the future.

\section{Results}

\subsection{Seafood production}




\subsubsection{Local production (PI\#1)}

Local Production of seafood is estimated at 20,424,242 $\pm 1,958,488 \mathrm{~kg}(\mu \pm$ SD) for the period 2009-2013 (Table 2). The non-commercial catch represents approximately 33\% of the annual catch in Hawai'i $(6,733,681 \mathrm{~kg}$; Fig. 2). For reef fisheries, the average annual catch (commercial + non-commercial) is $1,167,758 \pm 378,983 \mathrm{~kg}(\mu \pm \mathrm{SD})$ [50]. The average annual pelagic catch is $12,872,199 \pm 997,406 \mathrm{~kg}(\mu \pm S D)$ for the $2009-2013$ period. The bottom fishery provides an average annual catch of $172,978 \pm 21,844 \mathrm{~kg}(\mu \pm \mathrm{SD})$. The annual finfish and shellfish aquaculture production is estimated as $231,937 \mathrm{~kg} \pm 144,870 \mathrm{~kg}(\mu \pm \mathrm{SD})$ [50].

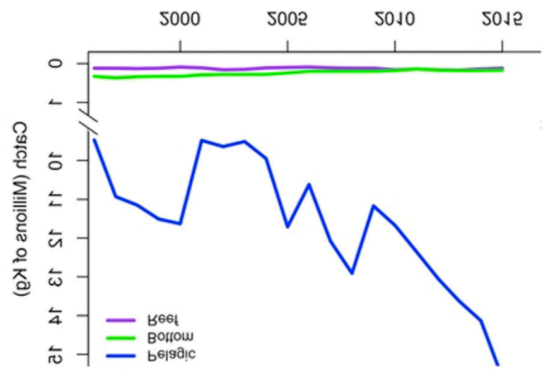

Fig 2. Trends in local production (1996-2015) for commercial pelagic, bottom, reef, and other fisheries (for more details and data table, see Supplementary Material, Table S1).

Statewide long-term records of catch are only available for commercial fisheries. While these catch reports are only part of the total Local Production, the authors used reported commercial catch to examine trends in local production. Commercial fishery reports show that, on average, catch has been increasing for the last 20 years, with pelagic catch contributing more than $90 \%$ of the reported commercial catch every year (Fig. 2). Overall, commercial bottomfish catches have been declining, and reef fish commercial catches have remained fairly stable, with average of $127,452 \mathrm{~kg}$ per year ( $\pm 23,820 \mathrm{~kg} \mathrm{SD}$ ). Trends in noncommercial (subsistence, recreational, cultural) fisheries production are more difficult to discern as total production estimates have only been recently developed at the statewide level, and because data paucity and other constraints preclude the development of temporal trends $[50,51]$.

Table 2. Mean annual seafood production from major production sources, used to calculate Local Production. Marine aquaculture includes finfish and shellfish only.

\begin{tabular}{llll}
\hline Major Production Sources & Commercial & Non-commercial & Total Mean Production per Year (kg) \\
\hline Pelagic fisheries & $12,872,199(63 \%)$ & $5,359,225(26.2 \%)$ & $18,231,424$ \\
Bottomfish fisheries & $172,977(0.8 \%)$ & $391,609(1.9 \%)$ & 564,586 \\
Reef fisheries & $184,911(0.9 \%)$ & $982,847(4.8 \%)$ & $1,167,758$ \\
Other fisheries & $228,538(1.1 \%)$ & & 228,538 \\
Marine aquaculture & $231,937(1.1 \%)$ & & 231,937 \\
Local Production & $13,690,562$ & $6,733,681$ & $20,424,243$ \\
\hline
\end{tabular}

\subsubsection{Total locally available seafood (TLAS) (PI\#2)}

The Total Locally Available Seafood (TLAS) was estimated at $32,450,820 \pm 1,571,905 \mathrm{~kg}(\mu \pm$ SD) per year for the period 2009-2013. This estimate represents the combined total annual seafood 
from both local and imported sources, minus annual exports (Table 3, Fig. 3). Foreign imports are estimated to add an additional production of 10,279,304 $\pm 513,615 \mathrm{~kg}(\mu \pm$ SD) of seafood per year to Local Production. Average annual exports for 2009-2013 were estimated to be $2,689,923 \pm 507,185 \mathrm{~kg}(\mu \pm S D)$, including re-exports of imported product in the total exports sum $[35,44]$. It is estimated that more than $1,150,000 \mathrm{~kg}$ is imported annually into Hawai' $i$, from poorly documented sources, including $\sim 1,134,000 \mathrm{~kg}$ from the continental U.S. [35], 14,397 kg from commercial seafood dealers importing coral reef food fish [36], and 22,949 kg from passengers on commercial airliners arriving from other Pacific Islands [28]. In essence, the net result of annual seafood trade flows for the period studied was $12,026,577 \mathrm{~kg}$, which is added to the local annual production estimated at $20,424,242 \mathrm{~kg}$, for a total of $32,450,820 \pm 1,571,905$ kg (Table 3).

Table 3. Seafood trade flows from foreign and domestic markets, for Hawai'i annually, for 2009-2013. *indicates re-exported seafood.

\begin{tabular}{llll}
\hline Trade Flows & & Imports (kg) & Exports (kg) \\
\hline Foreign markets & Direct import & $10,279,304$ & $1,055,286$ \\
& Imports through U.S. transhipments & $3,265,870$ & $228,497 *$ \\
& Commercial dealers importing unreported nearshore fish & 22,949 & \\
& Seafood imported in passenger luggage & 14,397 & $1,133,980$ \\
U.S. markets & & $\mathbf{1 4 , 7 1 6 , 5 0 0}$ & $1,406,140$ \\
Subtotal: & & & $\mathbf{2 , 6 8 9 , 9 2 3}$ \\
\hline
\end{tabular}

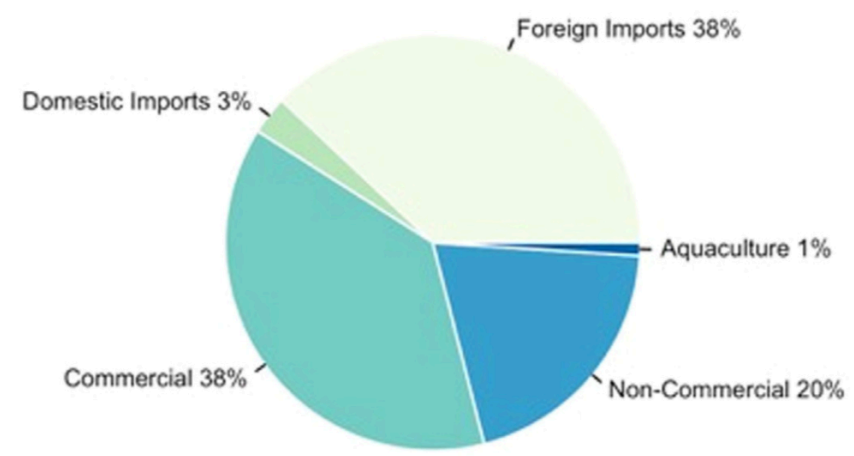

Fig. 3. Estimates of the composition of seafood sources for Hawai'i (Total Locally Available Seafood). Exports are included in the composition estimates (i.e., already subtracted from Local Production estimate) available from commercial trade flow data; it is unknown how much is exported from each cate- gory in the non-commercial sector or in total from aquaculture.

\subsubsection{Seafood self-sufficiency ratio (PI\#3)}

Seafood Self-Sufficiency Ratio (SSR) is $62.9 \% \pm 1.5 \%$. In other words, if all locally sourced seafood (i.e., all Local Production) were to stay in Hawai'i and if none were to be exported, local seafood sources (commercial, non-commercial, and aquaculture) would provide $63 \%$ of the seafood demand. By comparison, if exports are subtracted from the Local Production and then divide by the Total Locally Available Seafood, then the result is a true SSR of $55 \% \pm 1.5 \%$.

\subsubsection{Seafood import dependency ratio (PI\#4)}


The Seafood Import Dependency Ratio (SDR) (i.e., imported seafood divided by the TLAS) is $45.0 \% \pm 1.8 \%$. Therefore, Hawai' $i$ imports contribute almost half of the seafood consumed in the islands.

\subsubsection{Seafood provided per capita by TLAS (PI\#5)}

The Total Locally Available Seafood for Hawai'i $(32,450,820 \mathrm{~kg} \pm 1,571,905 \mathrm{~kg})$ accounts for about $134 \pm 6.5$ million meals available every year. This translates into roughly $98 \pm 5$ Meals Per Person (MPP) per year for all of Hawai'i's residents (based on latest available census data at the time of analysis, [47]). This is equivalent to about 5 weeks worth of food per person, or about $10 \%$ of Hawaiian residents' food supply for a given year. This translates to a per capita demand of $16.5 \mathrm{~kg}$ seafood per year provided per capita (SPPC). This number can also be calculated as the TLAS $(32,450,820 \mathrm{~kg})$ multiplied by 0.7 , assuming $70 \%$ is edible weight, and then dividing by the average Hawaii resident population of 1,376,222 people for 2009-2013, yielding $16.5 \mathrm{~kg}$ per capita per year. The $16.5 \mathrm{~kg}$ estimate presented here corroborates an earlier estimate of 16.7 kg calculated for 2000-2009 [35]). Both the seafood consumption per capita estimate this study offers and the one offered by Geslani et al. (2012) [35] use population estimates which include residents of Hawai' $i$ and military personnel stationed on the islands, but not tourists. While it is estimated that visitors to Hawaii spend approximately $\$ 250$ million on seafood every year, residents including military personnel spend more than $\$ 400$ million per year on seafood [35]. However, no data are available on total consumption of seafood by tourists in terms of total seafood weight.

\subsection{Seafood consumption and demand}

\subsubsection{CI\#1: future seafood demand}

Using population growth models for 2015-2040 from the State of Hawai'i, together with lower and upper bounds of seafood demand per capita of $16.5 \mathrm{~kg}$ [this study) and $16.7 \mathrm{~kg}$ [35], respectively, a range of Future Seafood Demand (FSD) is determined in Hawai'i from 2015 to 2040. The analysis suggests that total FSD in 2040 will range between $28,196,850 \mathrm{~kg}$ and $28,538,630 \mathrm{~kg}$, with an average of $28,367,740 \pm 241,675 \mathrm{~kg}(\mu \pm$ SD) (Fig. 4, Table S2), which would be $38-40 \%$ greater than 2013 levels of Local Production.

If an assumption is made that 2013 levels of Local Production remain constant, then authors projected that locally sourced seafood in Hawai'l (Local Production) will have a smaller and smaller contribution to Total Locally Available Seafood (TLAS), declining from $88 \%$ in 2015 to $72 \%$ in 2040 (Table S1).

\subsubsection{Cl\#2: future production gap (FPG)}

The Future Production Gap by 2040 is projected to be equivalent to at least 7,943,498 kg \pm $241,675 \mathrm{~kg}(\mu \pm$ SD) if 2013 levels of Local Production are sustained constant annually by 2040 . 


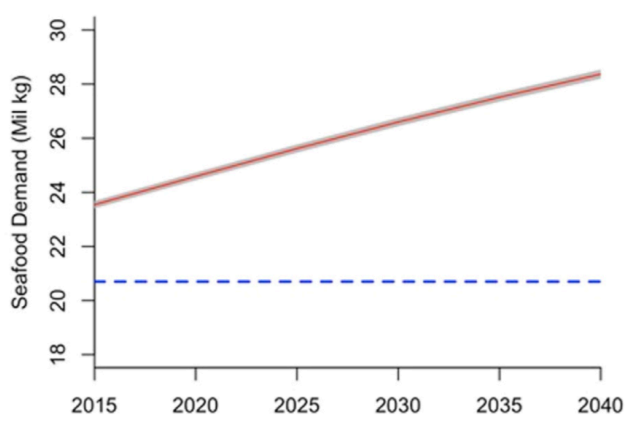

Fig. 4. Total seafood demand in Hawai'i by 2040, projected with 2 different per capita seafood demand scenarios. Grey area shows the envelope of projections based on the $12.9 \mathrm{~kg}$ and 16.7 kg per capita seafood demand estimates. Red line shows the average total seafood demand growth, and the purple line shows constant local commercial and non-commercial landings in Hawai'i for reference.

\subsubsection{Cl\#3: future seafood market price}

The analysis shows that average Future Seafood Market Price will rise from \$23.9 kg-1 in 2011 to $\$ 31.9 \mathrm{~kg}-1$ in 2040, an increase of 33\% in reference to 2015 USD, or approximately $1 \%$ per year.

\subsubsection{Cl\#4: future seafood household expenditures}

Even though the total amount of spending on seafood in absolute terms would increase, the annual household spending on seafood is estimated to decline as a fraction of total food budgets, from approximately $11.2 \%$ in 2015 to $9.8 \%$ by 2040 . For comparison, the national average for seafood expenditures in the U.S. is $6 \%$ of annual food budgets [49].

\section{Discussion}

This study provides a regional scale, quantitative assessment of the seafood sector's role in the food security for the people of Hawai' $i$, an example of an ocean-dependent island economy. Our analysis reveals several key insights relevant for food systems policy and sustainability targets, and securing the supply of seafood through effective management of production sectors, which are discussed below.

\subsection{Implications for food systems sustainability}

The most isolated archipelago on the planet, Hawai'i was once fully self-sufficient but is now reliant on outside sources of food to meet current local demand. Currently, only $13 \%$ of all food needed in Hawai' $i$ is sourced locally, with $81 \%$ imported from the continental U.S. and $6 \%$ from foreign sources (Fig. 5) [26]. The estimates here confirm that seafood has relatively low import dependency for Hawai' $i$, compared to other sources of protein, grains, fruits and vegetables [26]. However, seafood in Hawai'i comprises a small fraction of the total food supply - just 2.9\% - of the 1,142 million tonnes calculated for 2010 [26]. 
Seafood is, therefore, a bright spot in the overall food system, providing a relatively higher degree of self-sufficiency than other food sources; more than $60 \%$ of fresh vegetables and dairy products and all grain products available in the archipelago are imported [26]. This analysis shows that at current, $55 \%$ of locally available seafood is from local sources, with $45 \%$ coming from imports. The accuracy of these estimates is primarily attributed to more accurate estimates of production from non-commercial fisheries, which are prevalent in this geography $[50,51]$. Even with this high degree of self-sufficiency, Hawai'i continues to rely substantially on offshore production sources, i.e., imports from abroad and from the U.S. mainland (Table 3). Additionally, some seafood is also exported. It is likely that the amount of seafood export from Hawai' $i$, from the nearshore fisheries specifically, to the US mainland and abroad is underestimated, and if that were the case, then the self-sufficiency ratio (SSR) would be lower than $55 \%$.

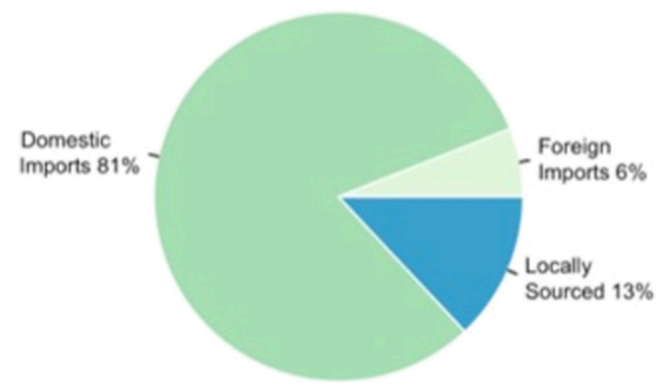

Fig. 5. Total food supply overall for Hawai'i for 2010 (Loke and Leung [26]).

\subsubsection{Future seafood demand, distribution channels, and access barriers}

With increases in population, the future seafood demand is projected to grow, widening the production gap (Fig. 4). If unaddressed, this fish protein production gap is likely to have negative consequences for food security, requiring increased reliance on imports. Additionally, as prices for seafood are predicted to increase, low-income households may face economic barriers to accessing seafood. While the percentage of annual food budgets spent on seafood in 2040 may decrease in relative terms, overall seafood and food costs are expected to go up by more than $30 \%$ by 2040 . Access barriers are important to consider because food security is dependent not only on the availability of sufficient quantities of food, but also on people's access to food, which are mediated by economic, social, and institutional factors [38].

The demand for seafood is typically inelastic in the U.S. and in Hawai'i, meaning that higher prices may not affect local demand. However, there may be an 'upset price' that creates a threshold of affordability, driving consumers to switch to other protein sources. In Hawai'i, a high fraction of low-income households $(<\$ 35,000$ per year) are also high consumers of seafood (i.e., more than $20 \%$ of their protein comes from seafood) [27]. An 'upset price' scenario may therefore be most relevant for low-income, high-seafood-consumer households in Hawai'i, which are prevalent in many rural locations in the archipelago. Increases in price could drive the transformation of seafood into more of a luxury good, depriving low-income 
households of this nutritious protein source and impacting the cultural use of seafood in local culinary traditions.

Notably, Hawai' $i$ is a relatively well-developed archipelago with a high GDP compared to other Pacific Island countries and territories, many consumers in Hawai'i have the ability to replace seafood with other protein sources. It is worth noting, however, that replacement foods are often less healthy, associated with deleterious dietary shifts that can increase the prevalence of chronic/lifestyle diseases [35], and may disrupt important cultural practices associated with harvesting and culinary traditions. The health and cultural implications of substitutability have been documented in the Pacific $[35,52,53]$. Additionally, it is notable that for some rural populations in the state, if fisheries are degraded to the point where harvesting becomes unviable as a food provisioning function, it may have serious impacts on food security and impoverished communities may not be able to afford alternatives [54].

Most of Hawai'i's seafood comes from pelagic fisheries, which have a high-value and are key in terms of generating revenue in the seafood industry. This commercial pelagic fishery swamps the ability of local markets to absorb this high-value product, and a substantial portion is exported to the U.S. mainland and to foreign markets. Hawai' $i$ also imports seafood that is not available locally but which residents and visitors have a preference for (e.g. salmon, whitefish, some shellfish). This commercial market, therefore, plays an important role in food production, but also in supporting livelihoods and market presence nationally and globally.

Non-commercial fisheries, on the other hand, play a major role in the subsistence economy, providing millions of meals per year directly to households $[28,45,55,56]$. A substantial percentage of this seafood is shared via social kinship networks $[57,58]$. This food distribution system plays a major role in the informal economy, is highly prevalent, and supports food security in communities across the archipelago. Ensuring the persistence of these activities should be a key policy priority in order to support the cultural traditions and food security of local communities.

\subsubsection{Meeting sustainability targets}

The State of Hawai'i has committed to several statewide sustainability targets, including a target to double local food production by 2020 . These goals are encompassed in the Aloha+ Challenge, and have been codified in the Governor's Sustainable Hawai'i Initiative [59]. Additionally, the Promise to Pae'Āina initiative [60] established a set of five commitments around ocean stewardship as part of the worldwide voyage of the Hōkūle'a, a traditional Hawaiian voyaging canoe, which involved extensive stakeholder consultation, buy-in, and implementation plans predicated around improving the sustainability of Hawai'l during the worldwide voyage of the Hōkūle'a (a traditional Hawaiian voyaging canoe). Finally, the locally adapted Hawai'i Ocean Health Index tracks regional ocean goals, including seafood provision and sustainability, and is being used to provide information for policy and decision makers [61]. 
These local targets and initiatives are important because they provide visible, agreed-upon goals that a diverse set of actors can align around, supported by a shared measurement to evaluate progress [62] and agreed-upon implementation plans. These elements are critical for collective action initiatives, particularly those that require changes to complex systems [63]. As the state implements actions to improve its self-sufficiency in food provisioning, this assessment can be used to track changes in the seafood system and its contributions to local food security. As this analysis has revealed that the seafood sector is one of the more selfsufficient aspects of our food system, it may also offer lessons learned for assessing the contribution of other systems and the fish protein production gap required to meet the goal of doubling local food production.

Because Hawai' $i$ is an island archipelago, this assessment and approach may also be relevant to other small island developing states (SIDS) that face similar distance from markets, economic development challenges, and natural resource endowments associated with their ocean resources. SIDS face unique challenges at the nexus of ocean health and food security, particularly in achieving progress United Nations Sustainable Development Goals (SDGs). Most relevant to this challenge are SDG2, which aims to end hunger and focuses on food security and nutrition; SDG8, which aims for decent work and economic growth for all; and SDG12, which focuses on responsible production and consumption. SDG14 focuses on conserving and sustainably using oceans [64]. These food-focused (SDGs 2, 8, 12) and ocean-focused (SDG 14) goals are closely intertwined in these systems. In recognition of this, leadership is building among governments, nonprofits, and the private sector to move toward responsible ocean stewardship that secures fair and equitable benefits for ocean-dependent communities [6568]. Networks such as the Global Island Partnership and global events such as the recent UN Oceans Conference in New York in 2017 provide opportunities for the efforts of individual islands to share their experiences and best practices, including on sustainable production of ocean resources.

\subsection{Policy options for increased resiliency in seafood systems}

Sustaining the food provisioning functions of seafood requires effective management of wildcapture fisheries, and aquaculture, which now accounts for approximately half of global production [11]. Wild capture fisheries have variable performance, with well-managed fisheries providing more security and predictable production. In contrast, overexploited fisheries underperform with respect to production, and require rebuilding plans that can produce tangible benefits. In 2004, an analysis by the World Bank showed that ineffective governance accounts for USD \$50 billion in lost revenue [69]. More recent analyses have shown that investments in better management will support better food security $(12,000,000$ metric tons more annually), more fish biomass (36\% increase), and more economic prosperity, including up to USD \$75 billion in value [70]. Aquaculture will also be critical to ensuring that ocean-based food production systems can continue to support global food demand in a fair and equitable way, taking into account the reliance of this sector on other food commodities and production landscapes/seascapes [39,71]. 
These global trends mask variable performance at regional and local scales. Pacific Island countries and territories, including Hawai'i, have a high reliance on ocean-based economic activities, including the seafood sector. In these vulnerable geographies, seafood is a culturally significant part of local culture, and historically was pivotal in the diets and subsistence strategies of pre-contact Polynesian populations[72,73]. As the Hawaiian archipelago has experienced significant postcolonial changes in its economy and modes of production, the seafood sector has experienced changes in both the dominant modes of production as well as the productivity of fisheries and aquaculture sectors [74-76]. Below options are discussed for improving the management of major seafood production sectors, securing supply for local food security and livelihoods.

\subsubsection{Recovering nearshore fisheries}

Nearshore coastal fisheries in Hawai'i have declined significantly over the last several decades $[77,78]$, and recent landings for many commercially harvested species are $<1 \%$ of maximum landings $[79,80]$. These declines are associated with a range of impacts reaching back for centuries, including land-based pollution, overfishing, and invasive species [73]. Climate change is a relatively recent threat to reef fisheries in Hawai' $i$, but a recent spate of archipelago-wide bleaching events portends a future of more significant impacts that pose serious risks for the viability of reefs and fisheries benefits.

Reef fisheries can be rebuilt by regulating input (effort) and output (catch) through effective management, together with protected areas that restrict harvesting. Catch and effort restrictions are common in reef fisheries worldwide, and Hawai'i has adopted many such measures. However, these measures have not been effective in recovering nearshore fisheries, which are significantly diminished in many locations [76,81]. Fisheries management areas, including closures based on traditional and customary practices, are effective at preserving populations and rebuilding stocks in Hawai'i and similar geographies [82,83]. Implementing these approaches requires investment in scoping, development, and implementation of management systems, but scientific evidence shows the benefits of rebuilding through effective management far outweigh the costs, and significant long-term benefits for the seafood sector can accrue [70,84]. A greater investment in regional systems of fisheries management areas, based on successful models such as the West Hawaii Fishery Management Council [83], could enhance or protect the productive capacity of nearshore fisheries.

Research on the connectivity of targeted species suggests that at a minimum, regional management structures that encompass entire islands (and in the case of Maui, the entirety of Maui, Lāna'i, and Molokai) are also required in order to adequately manage the relevant habitat and distribution of targeted species at ecologically relevant scales [85]. In Hawai'i, there is a good model for regional management in the West Hawaii Regional Fishery Management Council, which oversees a set of fishery replenishment areas that has shown success in managing a fishery for ornamental aquarium species $[83,86]$. This regional approach can provide a template for other similar efforts, matching key biological and social scales [76] and providing opportunities for the self-determination of communities to secure the important food 
provisioning functions of nearshore fisheries. Additionally, increased investment in monitoring catch and effort can help to inform the establishment of appropriate catch and effort restrictions to recover or conserve targeted species [50,51].

Establishing effective management has become even more of an imperative with the major threats associated with global climate change, which will have major impacts on reef fisheries [87]. Therefore it is also critical to reduce other major local stressors, including land-based pollution, invasive species, and other threats. For pollution control, recent research shows that targeted investments in remediation and restoration initiatives can produce significant impacts at relatively lower costs [88]. Similarly, large-scale efforts to control invasive species have also proven effective in specific geographies $[89,90]$. Current estimates for rebuilding reef fisheries in Hawai'i suggest this will require multiple decades [91], but the recovery trajectory will likely be variable by geography and can potentially be faster depending on the management options considered.

\subsubsection{Managing pelagic and bottomfish fisheries}

The vast majority of seafood in Hawai'i comes from pelagic fisheries (Fig. 2). Hawai'i's pelagic and bottomfish fisheries are managed in accordance with the Magnuson Stevens Fisheries Conservation Act, which establishes a regulatory structure and key management actions to ensure sustainable fisheries management. The pelagic fisheries primarily target highly migratory species that are fished by a variety of nations and territories throughout the Pacific, and are managed under a complex set of international regulatory regimes in the region. These fisheries are managed within the limits of sustainability and Hawai'i's fleet only comprises $<5 \%$ of the total effort for longline fisheries across the Pacific. Hawai'i's pelagic fleets fish primarily in the waters to the north and south of the archipelago and in recent years, the Hawai' $i$ fleet has had record catches that have caused the fleet to reach the quota for the Hawai' $i$-based fleet. Climate change is likely to change the distribution of tuna resources, which may affect access to, and abundance of these resources [92], which will require shifts in both domestic and international fishery management in order to ensure persistence of this vital resource.

While the total effort of the Hawai'i fleet is small relative to other major fishing nations, the benefit to Hawai'i's economy is significant. In recent years, the fleet has reached its annual quota very early in the year, resulting in closures that have been costly for the fishing fleets, as well as the buyers and distributors. During these closures, the supply of local pelagic species is greatly diminished, operators lose important revenue, and distributors often must rely on other sources to supply their buyers [93]. Federal regulations have been promulgated to reduce the impacts of these closures, but a long-term management strategy may be needed to ensure fishery is sustainably managed from a biological and socioeconomic standpoint, including better regulatory measures to prevent market disruptions. Catch-based systems have been implemented successfully in other geographies which can minimize these types of disruptions $[94,95]$, but important socioeconomic and governance attributes need to be considered in the adaptation of these approaches in Hawai' $i$ 's pelagic fisheries [96]. 


\subsubsection{Rebuilding aquaculture}

Hawai'i used to produce more than a 1 million kg per year from indigenous aquaculture production in traditional Hawaiian fishponds [97]. Once numbering in the hundreds, these systems suffered from centuries of impacts reducing production to minimal levels in recent years [70]. However, these systems are experiencing resurgence, with active restoration and piloting of production methods that mix traditional approaches with conventional aquaculture production systems [98]. Additionally, Hawai'i has become a hub for research and development of aquaculture innovations, supported by research institutions such as the Oceanic Institute of Hawai'i Pacific University and the Pacific Aquaculture \& Coastal Resources Center at the University of Hawai'i Hilo. Additionally, enterprise hubs such as the Hawai'i Ocean Science \& Technology Park at the Natural Energy Laboratory of Hawai'I Authority have fostered innovation in offshore and coastal aquaculture production sectors.

To determine if aquaculture production could help meet future production gap, the potential of local aquaculture, focusing on traditional fishpond aquaculture and other forms of seafood farming was modeled. Currently, there are 545.3 acres (220.7 ha) of actively managed fishponds in Hawai'i. These systems, when fully functional, have the potential for $300 \mathrm{lbs}$ (136.1 $\mathrm{kg}$ ) per-acre productivity, resulting in a total potential future production of $163,590 \mathrm{lbs}$ or $74,203 \mathrm{~kg}$ of seafood. This comprises $0.9 \%$ of the $7,832,950 \mathrm{~kg}$ production gap predicted by 2040.

Oceanic finfish and shellfish aquaculture is currently growing at $6 \%$ per year, and Hawai'i has several active production initiatives in the recent past and currently underway $[99,100]$. If offshore fish farming can grow from the current production level at a $6 \%$ rate, this would theoretically produce $1,767,728 \mathrm{~kg}$ per year by 2040 , further reducing the production gap by another $22.6 \%$. These calculations do not, however, incorporate (i) intensification of production methods within existing fishponds, (ii) the restoration of additional existing fishponds into productive status, (iii) the development of larger-scale offshore aquaculture, or (iv) land-based aquaculture production, all of which could provide additional sources of production.

Hawaii has strengths in research and development in aquaculture, supported by a range of academic institutions and centers (listed above) as well as in the private sector, which has enabled the aquaculture sector to increase to a total value of almost \$80 million (USD) in 2016 (State of Hawaii, Dept of Agriculture, unpublished data). This vibrant sector is creating the conditions for increased sustainable production of seafood. This area of strength can be accelerated by developing the commercial viability of innovations from the research sector, and by investing in social impact entrepreneurship to enable the growth of aquaculture businesses. This can be supported by increased grant aid to the sector as well as private sector investment in viable, scalable production operations. Notably, Hawai'i has played a globally significant role in major research developments in aquaculture, including specific pathogen free broodstock shrimp. Lastly, improvements in the permitting and regulatory environment could also help support business development. Streamlining these requirements via improving interagency collaborative permitting and compliance review processes, can 
ensure proper environmental oversight while also removing regulatory barriers that can carry costs. Recent successful efforts to streamline permitting conditions for traditional Hawaiian fishponds represent a good model that can be adopted more widely for the sector [101].

\section{Conclusion}

The ocean is the largest food system on earth, supporting the basic nutritional needs of over a billion people and the livelihoods of more than 260 million. This food provisioning function depends entirely on the sustainable management of ecosystems for wild-capture fisheries and aquaculture. In many coastal economies, the role of seafood is recognized but rarely has it been quantitatively assessed, precluding the development of strategies to support sustainable production. Our "State of the Plate" study shows that seafood is a critical contributor to local food security, with a high degree of self-sufficiency relative to other food sources. This area of strength in our local food system needs to be further supported by effective policy in order to support production under threats of climate change, increasing demand, and local stressors. Our approach may prove useful for other regional and local-scale efforts to assess the role of seafood in food security and to project and prepare for future changes in production, distribution, and consumption.

\section{Acknowledgments}

This work was supported by the National Oceanic and Atmospheric Administration's SaltonstallKennedy program, through award number NA15NMF4270332, granted to Conservation International. The authors thank Jason Chow, Jason Philibotte, Adam Ayers, David Delaney, and Justin Hospital for providing constructive input on previous versions of this manuscript.

\section{Appendix A. Supplementary material}

Supplementary data associated with this article can be found in the online version at http://dx.doi.org/10.1016/j.marpol.2018.04.025.

\section{References}

[1] D. Pauly, V. Christensen, S. Guenette, T. Pitcher, U. Sumaila, C. Walters, R. Watson, D. Zeller, Towards sustainability in world fisheries, Nature 418 (2002) 689-695, http://dx.doi.org/10.1038/nature01017.

[2] B. Worm, E.B. Barbier, N. Beaumont, J.E. Duffy, C. Folke, B.S. Halpern, J.B.C. Jackson, H.K. Lotze, F. Micheli, S.R. Palumbi, E. Sala, K.A. Selkoe, J.J. Stachowicz, R. Watson, Impacts of biodiversity loss on ocean ecosystem services, Science 314 (2006) 787-790, http://dx.doi.org/10.1126/science.1132294.

[3] B.S. Halpern, S. Walbridge, K. Selkoe, C.V. Kappel, F. Micheli, C. D’Agrosa, K.S. Casey, C. Ebert, H.E. Fox, R. Fujita, D. Heinemann, H.S. Lenihan, E.M. Madin, M.T. Perry, E.R. Selig, M. Spalding, R. Steneck, R. Watson, A global map of human impact on marine ecosystems, Science 319 (2008) 948-952, http://dx.doi.org/10.1126/science.1149345. 
[4] B.S. Halpern, C. Longo, D. Hardy, K.L. McLeod, J.F. Samhouri, S.K. Katona, K. Kleisner, S.E. Lester, J. O'Leary, M. Ranelletti, A.A. Rosenberg, C. Scarborough, E.R. Selig, B.D. Best, D.R. Brumbaugh, F.S. Chapin, L.B. Crowder, K.L. Daly, S.C. Doney, C. Elfes, M.J. Fogarty, S.D. Gaines, K.I. Jacobsen, L.B. Karrer, H.M. Leslie, E. Neeley, D. Pauly, S. Polasky, B. Ris, K. St Martin, G.S. Stone, U.R. Sumaila, D. Zeller, An index to assess the health and benefits of the global ocean, Nature 488 (2012) 615-620, http://dx.doi.org/10.1038/nature11397.

[5] Millennium Ecosystem Assessment (MA): Ecosystems and Human Well-being Synthesis. Washington, D.C, 2005.

[6] R.J. Diaz, R. Rosenberg, Spreading dead zones and consequences for marine ecosystems, Science 321 (2008) 926-929, http://dx.doi.org/10.1126/science.1156401.

[7] J.D. Bell, M. Kronen, A. Vunisea, W.J. Nash, G. Keeble, A. Demmke, S. Pontifex, S. Andrefouet, Planning the use of fish for food security in the Pacific, Mar. Policy 33 (2009) 6476, http://dx.doi.org/10.1016/j.marpol.2008.04.002.

[8] S. Hughes, A. Yau, L. Max, N. Petrovic, F. Davenport, M. Marshall, T.R. McClanahan, E.H. Allison, Cinner. A framework to assess national level vulnerability from the perspective of food security: the case of coral reef fisheries, Environ. Sci. Policy 23 (2012) 95-108, http://dx.doi.org/10.1016/j.envsci.2012.07.012.

[9] J.N. Kittinger, Participatory fishing community assessments to support coral reef fisheries comanagement, Pac. Sci. 67 (2013) 361-381, http://dx.doi.org/10.2984/67.3.5.

[10] S. Foale, D. Adhuri, P. Aliño, E.H. Allison, N. Andrew, P. Cohen, L. Evans, M. Fabinyi, P. Fidelman, C. Gregory, N.E. Stacey, J.M. Tanzer, N. Weeratunge, Food security and the Coral Triangle Initiative, Mar. Policy 38 (2013) 174-183, http://dx.doi.org/10.1016/j.marpol.2012.05.033.

[11] Food and Agriculture Organization UN (FAO). The State of World Fisheries and Aquaculture: Opportunities and Challenges. FAO, Rome. [online] 〈www.fao.org/3/ai5798e.pdf $\rangle$.

[12] K. Newton, I.M. Cote, G.M. Pilling, S. Jennings, N.K. Dulvy, Current and future sustainability of island coral reef fisheries, Curr. Biol. 17 (2007) 655-658, http://dx.doi.org/10.1016/j.cub.2007.02.054.

[13] M. Kronen, F. Magron, B. McArdle, A. Vunisea, Reef finfishing pressure risk model for Pacific Island countries and territories, Fish. Res. 101 (2010) 1-10, http://dx.doi.org/10.1016/i.fishres.2009.08.011.

[14] M. Kronen, A. Vunisea, F. Magron, B. Mcardle, Socio-economic drivers and indicators for artisanal coastal fisheries in Pacific island countries and territories and their use for fisheries 
management strategies, Mar. Policy 34 (2010) 1135-1143,

http://dx.doi.org/10.1016/j.marpol.2010.03.013.

[15] K.E. Charlton, J. Russell, E. Gorman, Q. Hanich, A. Delisle, B. Campbell, J. Bell, Fish, food security and health in Pacific Island countries and territories: a systematic literature review, BMC Public Health 2016 (16) (2016) 285, http://dx.doi.org/10.1186/s12889-016-2953-9.

[16] A. Levine, L. Richmond, Examining enabling conditions for community-based fisheries comanagement: comparing efforts in Hawai'i and American Samoa, Ecol. Soc. 19 (2014) 24, http://dx.doi.org/10.5751/ES-06191-190124.

[17] T.P. Hughes, A.H. Baird, D.R. Bellwood, M. Card, S.R. Connolly, C. Folke, R. Grosberg, O. Hoegh-Guldberg, J.B.C. Jackson, J. Kleypas, J.M. Lough, P. Marshall, M. Nystrom, S.R. Palumbi, J.M. Pandolfi, B. Rosen, J. Roughgarden, Climate change, human impacts, and the resilience of coral reefs, Science 301 (2003) 929-933, http://dx.doi.org/10.1126/science.1085046.

[18] T.P. Hughes, M.J. Rodrigues, D.R. Bellwood, D. Ceccarelli, O. Hoegh-Guldberg, L. McCook, N. Moltschaniwskyi, M.S. Pratchett, R.S. Steneck, B. Willis, Phase shifts, herbivory, and the resilience of coral reefs to climate change, Curr. Biol. 17 (2007) 360-365, http://dx.doi.org/10.1016/j.cub.2006.12.049.

[19] D.R. Bellwood, T.P. Hughes, C. Folke, M. Nyström, Confronting the coral reef crisis, Nature 429 (2004) 827-833, http://dx.doi.org/10.1038/nature02691.

[20] O. Hoegh-Guldberg, P.J. Mumby, A.J. Hooten, R.S. Steneck, P. Greenfield, E. Gomez, C.D. Harvell, P.F. Sale, A.J. Edwards, K. Caldeira, N. Knowlton, C.M. Eakin, R. Iglesias-Prieto, N. Muthiga, R.H. Bradbury, A. Dubi, M.E. Hatziolos, Coral reefs under rapid climate change and ocean acidification, Science 318 (2007) 1737-1742, http://dx.doi.org/10.1126/science.1152509.

[21] P.J. Mumby, Phase shifts and the stability of macroalgal communities on Caribbean coral reefs, Coral Reefs 28 (2009) 761-773, http://dx.doi.org/10.1007/s00338-009-0506-8.

[22] J.D. Bell, N.L. Andrew, M.J. Batty, L.B. Chapman, J.M. Dambacher, B. Dawson, A.S. Ganachaud, P. Gehrke, J. Hampton, A.J. Hobday, O. Hoegh-Guldberg, J.E. Johnson, J. Kinch, E. Le Borgne, P. Lehodey, J.M. Lough, T. Pickering, M.S. Pratchett, A. Vunisea, M. Waycott, Adapting tropical Pacific fisheries and aquaculture to climate change: management measures, policies and investments, in: J.D. Bell, J.E. Johnson (Eds.), book: Vulnerability of Tropical Pacific Fisheries and Aquaculture to Climate Change, Publisher: Secretariat of the Pacific Community, AJ Hobday, 2011, pp. 803-874.

[23] L. Burke, K. Reytar, M. Spalding, A. Perry, Reefs at Risk, World Resources Institute, Washington, D.C., 2011. 
[24] J.D. Bell, A. Ganachaud, P.C. Gehrke, S.P. Griffiths, A.J. Hobday, O. HoeghGuldberg, J.E. Johnson, E. Le Borgne, P. Lehodey, J.M. Lough, R.J. Matear, T.D. Pickering, M.S. Pratchet, A.S. Gupta, I. Senina, M. Waycott, Mixed responses of tropical Pacific fisheries and aquaculture to climate change, Nat. Clim. Change 3 (2013) 591-599, http://dx.doi.org/10.1038/nclimate1838.

[25] T.P. Hughes, A.H. Baird, E. a. Dinsdale, N.A. Moltschaniwskyj, M.S. Pratchett, J.E. Tanner, B.L. Willis, Assembly rules of reef corals are flexible along a steep climatic gradient, Curr. Biol. 2012 (22) (2012) 736-741, http://dx.doi.org/10.1016/j.cub.2012.02.068.

[26] M. Loke, P.S. Leung, Hawai'i's food consumption and supply sources: benchmark estimates and measurement issues, Agric. Food Econ. (2013) 2013, http://dx.doi.org/10.2286/2193-7532-1-10.

[27] OmniTrack Group. Survey on Seafood Security. Honolulu, Hawaii, USA.

[28] S. Grafeld, K.L.L. Oleson, L. Teneva, J.N. Kittinger, Follow that fish: uncovering the hidden blue economy in coral reef fisheries, PLoS One 12 (8) (2017) e0182104, http://dx.doi.org/10.1371/journal.pone.0182104.

[29] Food and Agriculture Organization UN (FAO), An Introduction to the Basic Concepts of Food Security, Food and Agriculture Organization of the United Nations, Rome, 2008〈www.foodsec.org/docs/concepts guide.pdf).

[30] Food and Agriculture Organization UN (FAO), Implic. Econ. Policy Food Secur.: A Train. Man. (1999), 〈www.fao.org/docrep/004/x3936e/x3936e03.htm〉.

[31] J. Clapp, Food self-sufficiency: making sense of it, and when it makes sense, Food Policy 66 (2017) 88-96, http://dx.doi.org/10.1016/i.foodpol.2016.12.001.

[32] M.D. Anderson, J.T. Cook, Community food security: practice in need of theory? Agric. Human. Values 16 (1999) 141-150, http://dx.doi.org/10.1023/A:1007580809588.

[33] C.C. Hinrichs, The practice and politics of food system localization, J. Rural Stud. 19 (2003) 33-45, http://dx.doi.org/10.1016/S0743-0167(02)00040-2.

[34] P.J. Ericksen, Conceptualizing food systems for global environmental change research, Glob. Environ. Chang 18 (2008) 234-245, http://dx.doi.org/10.1016/j.gloenvcha.2007.09.002.

[35] C. Geslani, M. Loke, B. Takenaka, Hawai'i's Seafood Consumption and its Supply Sources Hawai'I's Seafood Consumption and its Supply Sources. Honolulu, Hawaii, USA, 2012.

[36] N.A. Milne, Coral reef fish dealer study (CRFDS) for the Hawaiian Islands. Honoka'a, Hawai'i: a report to the Western Pacific Regional Fishery Management Council, Okupukupu Consulting, LLC, 2012. 
[37] J. Hospital, C. Beavers, Hawaii retail seafood markets: observations from Honolulu (2007-2011), NOAA (2014), http://dx.doi.org/10.7289/V53R0QSM 〈https://www.pifsc.noaa.gov/library/pubs/admin/PIFSC_Admin_Rep_15-01.pdf〉.

[38] C. Hicks, J. Cinner, Social, institutional, and knowledge mechanisms mediate diverse ecosystem service benefits from coral reefs, Proc. Natl. Acad. Sci. 111 (2014) 17791-17796, http://dx.doi.org/10.1073/pnas.1413473111.

[39] C.D. Golden, K.L. Seto, M.M. Dey, O.L. Chen, J.A. Gephart, S.S. Myers, M. Smith, B. Vaitla, E.H. Allison, Does aquaculture support the needs of nutritionally vulnerable nations? Front. Mar. Sci. (2017) 4, http://dx.doi.org/10.3389/fmars.2017.00159.

[40] P. Dalzell, T.J.H. Adams, N.V.C. Polunin, Coastal fisheries in the Pacific islands, Oceanogr. Mar. Biol.: Annu. Rev. 34 (1996) 395-531.

[41] United States Department of Agriculture. National Agricultural Statistics Service (NASS). Hawaii Farm Facts. [online]

〈https://www.nass.usda.gov/Statistics by State/Hawaii/Publications/Hawaii_Farm_Facts/inde x.php $\rangle$.

[42] NOAA Pacific Islands Fisheries Science Center. Annual Reported Commercial Landings. [online] 〈https://www.pifsc.noaa.gov/wpacfin/hi/Data/Landings Charts/hr3a.htm〉, 2016.

[43] NOAA Marine Recreational Information Program. [online] 〈http://www.st.nmfs. noaa.gov/recreational-fisheries/data-and-documentation/run-a-data-query).

[44] National Marine Fisheries Service. Commercial Fisheries: Foreign Trade. [online] 〈http://www.st.nmfs.noaa.gov/commercial-fisheries/foreign-trade/〉.

[45] J.N. Kittinger, L.T. Teneva, H. Koike, K.A. Stamoulis, D.S. Kittinger, K.L. Oleson, E. Conklin, M. Gomes, B. Wilcox, A.M. Friedlander, From reef to table: social and ecological factors affecting coral reef fisheries, artisanal seafood supply chains, and seafood security, PloS One 10 (2015) e0123856, http://dx.doi.org/10.1371/journal.pone.0123856.

[46] Hawaii Department of Business, Economic Development and Tourism (HI DBEDT). Census Demographic Profile: Neighbor Islands. Honolulu, Hawaii. [online] 〈http://files.hawaii.gov/dbedt/census/Census 2010/demographic/demo_profile_ cdp NI/Lanaicity.pdf $\rangle$.

[47] Hawaii Department of Business, Economic Development and Tourism (HI DBEDT). Population and Economic Projections for the State of Hawaii to 2040. Honolulu, 
Hawaii, [online] 〈http://files.hawaii.gov/dbedt/economic/data reports/2040long-rangeforecast/2040-long-range-forecast.pdf).

[48] OECD-FAO. World Agricultural Outlook. Rome, Paris, 2012.

[49] United States Department of Agriculture. Official USDA Alaska and Hawaii Thrifty Food Plans: Cost of Food at Home. [online] 〈https://www.cnpp.usda.gov/USDAFoodPlansCostofFood), 2015.

[50] K.S. McCoy, I.D. Williams, A. Friedlander, H. Ma, L. Teneva, J.N. Kittinger Estimating nearshore coral reef-associated fisheries production from the main Hawaiian Islands. PLoS One 13(4): e0195840, DOI: 10.1371/journal.pone.0195840.

[51] D.G. Delaney, L.T. Teneva, K.A. Stamoulis, J.L. Giddens, H. Koike, T. Ogawa, A.M. Friedlander, J.N. Kittinger, Patterns in artisanal coral reef fisheries reveal best practices for monitoring and management, PeerJ 5 (2017) e4089, http://dx.doi.org/10.7717/peeri.4089.

[52] R. Taylor, D. Bampton, A.D. Lopez, Contemporary patterns of Pacific Island mortality, Int. J. Epidemiol. 34 (2005) 207-214.

[53] R. Taylor, The double disease burden in Pacific Island states (except Papua New Guinea), in: M.J. Lewis, K.L. MacPherson (Eds.), Health Transitions and the Double Disease Burden in Asia and the Pacific: Histories of responses to noncommunicable and communicable diseases. Routledge, London and New York, 2013.

[54] J.K. Matsuoka, D.P. McGregor, L. Minerbi, Molokai: a study of Hawaiian subsistence and community sustainability. Pages 25-43, in: M.D. Hoff (Ed.), Sustainable Community Development: Studies in Economic, Environmental, and Cultural Revitalization, CRC Press, 1998.

[55] E. Glazier, C. Carothers, N. Milne, M. Iwamoto, Seafood and society on O'ahu in the Main Hawaiian Islands, Pac. Sci. 67 (2013) 345-359, http://dx.doi.org/10.2984/67.3.4.

[56] C. Severance, R. Franco, M. Hamnett, C. Anderson, F. Aitaoto, Effort triggers, fish flow, and customary exchange in American Samoa and the Northern Marianas: Critical Human Dimensions of Western Pacific Fisheries, Pac. Sci. 67 (2013) 383-393, http://dx.doi.org/10.2984/67.3.6.

[57] J.N. Kittinger, J.Z. Koehn, E. Le Cornu, N.C. Ban, M. Gopnik, M. Armsby, C. Brooks, M.H. Carr, J.E. Cinner, A. Cravens, M. D'lorio, A. Erickson, E.M. Finkbeiner, M.M. Foley, R. Fujita, S. Gelcich, K. St Martin, E. Prahler, D.R. Reineman, J. Shackeroff, C. White, M.R. Caldwell, L.B. Crowder, A practical approach for putting people in ecosystem-based ocean planning, Front. Ecol. Environ. (2014), http://dx.doi.org/10.1890/130267. 
[58] M. Vaughan, P. Vitousek, Mahele: sustaining communitites small-scale inshore fishery catch and sharing networks, Pac. Sci. (2013) 67, http://dx.doi.org/10.2984/67.3.3.

[59] Governor's Sustainable Hawai'i Initiative. [online] 〈http://governor.hawaii.gov/sustainablehawaii-initiative/ $/$.

[60] Promise to Pae'Aina Initiative. [online] 〈http://www.hokulea.com/promise-topaeaina/〉.

[61] Hawaii Ocean Health Index. [online] 〈http://www.ohi-science.org/mhi $\rangle$.

[62] Aloha+ Challenge Dashboard. [online] 〈https://dashboard.hawaii.gov/alohachallenge), 2017.

[63] J. Kania, M. Kramer, Collect. Impact Stanf. Social. Innov. Rev. Winter (2011) 36-41 〈https://ssir.org/articles/entry/collective impact).

[64] United Nations Sustainable Development Goals, [online] 〈https://sustainabledevelopment.un.org/sdgs $\rangle, 2016$.

[65] D. Le Blanc, C. Freire, M. Vierros, Mapping the linkages between oceans and other Sustainable Development Goals: A preliminary exploration. Department of Economic \& Social Affairs, DESA Working Paper No. 149. ST/ESA/2017/DWP/149, [online] 〈https://www.un.org/development/desa/publications/workingpaper/wp149), 2017.

[66] S. Unger, A. Müller, J. Rochette, S. Schmidt, J. Shackeroff, G. Wright, Achieving the Sustainable Development Goal for the oceans, Inst. Adv. Sustain. (IASS) (2017) (IASS Policy Brief 1/2017, Potsdam,) (online), 〈http://www.iasspotsdam.de/sites/default/files/files/policy brief 12017 en archieving the sdgs for oceans. pdf).

[67] Nereus Program. Oceans and the Sustainable Development Goals: Co-Benefits, Climate Change \& Social Equity. The Nippon Foundation, Nereus Program. [online] 〈http://www.nereusprogram.org/wp-content/uploads/2017/05/SDGReport-2017-onlineversion.compressed.pdf $\rangle$.

[68] J.N. Kittinger, L.C.L. The, E.H. Allison, N.J. Bennett, L.B. Crowder, E.M. Finkbeiner, C. Hicks, C.G. Scarton, K. Nakamura, Y. Ota, J. Young, A. Alifano, A. Apel, A. Arbib, L. Bishop, M. Boyle, A.M. Cisneros-Montemayor, P. Hunter, E. Le Cornu, M. Levine, R.S. Jones, J.Z. Koehn, M. Marschke, J.G. Mason, F. Micheli, L. McClenahan, C. Opal, J. Peacey, S.H. Peckham, E. Schemmel, V. Solis-Rivera, W. Swartz, T.A. Wilherm, Committing to socially responsible seafood, Science 356 (2017) 912-913, http://dx.doi.org/10.1126/science.aam9969.

[69] World Bank: The Sunken Billions: The economic justification for fisheries reform. 
FAO, Rome, The World Bank, Washington D.C. [online]

〈https://siteresources.worldbank.org/EXTARD/Resources/336681-

1224775570533/SunkenBillionsFinal.pdf), 2004.

[70] C. Costello, D. Ovando, T. Clavelle, C.K. Strauss, R. Hilborn, M.C. Melnychuk, T.A. Branch, S.D. Gaines, C.S. Szuwalski, R.B. Cabral, R.N. Rader, A. Leland, Global fishery prospects under contrasting management regimes, Proc. Natl. Acad.

Sci. 113 (2016) 5125-5129, http://dx.doi.org/10.1073/pnas.1520420113.

[71] M. Troell, R.L. Naylor, M. Metian, M. Beveridge, P.H. Tyedmers, C. Folke, K.J. Arrow, S. Barrett, A.S. Crépin, P.R. Ehrlich, Does aquaculture add resilience to the global food system? Proc. Natl. Acad. Sci. 111 (2017) 13257-13263, http://dx.doi.org/10.1073/pnas.1404067111.

[72] P.V. Kirch, T.L. Hunt, Historical Ecology in the Pacific Islands: prehistoric Environmental and Landscape Change, Yale University Press, New Haven, CT, 1997.

[73] J.N. Kittinger, J.M. Pandolfi, J.H. Blodgett, T.L. Hunt, H. Jiang, Kepa Maly, L.E. McClenahan, J.K. Schultz, B.A. Wilcox, Historical reconstruction revelas recovery in Hawaiian coral reefs, PLos One 6 (10) (2011) e25460, http://dx.doi.org/10.1371/journal.pone.0025460.

[74] B.A. Costa-Pierce, Aquaculture in ancient Hawai'i, BioScience 37 (1987) 320-331, http://dx.doi.org/10.2307/1310688.

[75] D.M. Schug, Hawai'i's commercial fishing industry: 1820-1945, Hawaii. J. Hist. 35 (2001) 15-34 (DOI: http://hdl.handle.net/10524/637).

[76] A.M. Friedlander, M.K. Donovan, K.S. Stamoulis, I.D. Williams, E.K. Brown, E.J. Conklin, E.E. DeMartini, K.S. Rodgers, R.T. Sparks, W.J. Walsh, Human-induced gradients of reef fish declines in the Hawaiian Archipelago viewed through the lens of traditional management boundaries, Aquat. Conserv.: Mar. Freshw. Ecosyst. (2017), http://dx.doi.org/10.1002/aqc.2832.

[77] A. Friedlander, G. Aeby, R. Brainard, E. Brown, K. Chaston, A. Clark, P. McGowan, P. Montgomery, W. Walsh, I. Williams, W. Wiltse, The state of coral reef ecosystems of the Main Hawaiian Islands (NOAA Technical Memorandum NOS NCCOS 73), in: J.E. Waddell, A.M. Clarke (Eds.), The State of Coral Reef Ecosystems of the United States and Pacific Freely Associated States, NOAA/NCCOS Center for Coastal Monitoring and Assessment's Biogeography Team, Silver Spring, MD, 2008, pp. 219-261.

[78] L.M. Wedding, J. Lecky, J.M. Gove, H.R. Walecka, M.K. Donovan, G.J. Williams, J.B. Jouffray, L.B. Crowder, A. Erickson, K. Falinski, A.M. Friedlander, C.V. Kappel, J.N. Kittinger, K. McCoy, A. Norstrom, M. Nystrom, Oleson KLL, K.A. Stamoulis, C. White, K.A. Selkoe, Advancing the integration of spatial data to map human and natural drivers on coral reefs, PLoS One 13 (3) (2018) e0189792, http://dx.doi.org/10.1371/journal.pone.0189792. 
[79] A.M. Friedlander, K.A. Stamoulis, J.N. Kittinger, J.C. Drazen, B.N. Tissot, Understanding the scale of marine protection in Hawai' $\mathrm{i}$ : From community-based management to the remote Northwestern Hawaiian Islands. Chapter 5, Advances in Marine Biology: Marine Managed Areas and Fisheries, vol. 69, M.L. Johnson, J. Sandell, (eds), 2014.

[80] L. McClenachan, J.N. Kittinger, Multicentury trends and the sustainability of coral reef fisheries in Hawaii and Florida, Fish. Fish. 14 (2012) 239-255, http://dx.doi.org/10.1111/j.14672979.2012.00465.x.

[81] M.O. Nadon, J.S. Ault, I.D. Williams, S.G. Smith, G.T. DiNardo, Length-Based Assessment of Coral Reef Fish Populations in the Main and Northwestern Hawaiian Islands, PLoS One 10 (2015) e0133960, http://dx.doi.org/10.1371/journal.pone.0133960.

[82] B.N. Tissot, W.J. Walsh, M.A. Hixon, Hawaiian islands marine ecosystem case study: ecosystem- and community-based management in Hawai'i, Coast. Manag. 37 (2009) 255-273, http://dx.doi.org/10.1080/08920750902851096.

[83] T.C. Stevenson, B.N. Tissot, W.J. Walsh, Socioeconomic consequences of fishing displacement from marine protected areas in Hawai'i, Biol. Conserv. 160 (2013) 50-58, http://dx.doi.org/10.1016/j.biocon.2012.11.031.

[84] R. Hilborn, C. Costello, The potential for blue growth in marine fish yield, profit and abundance of fish in the ocean, Mar. Policy (2017), http://dx.doi.org/10.1016/i.marpol.2017.02.003.

[85] R.J. Toonen, K.R. Andrews, I.B. Baums, C.E. Bird, G.T. Concepcion, T.S. DalyEngel, et al., Defining boundaries for ecosystem-based management: a multispecies case study of marine connectivity across the Hawaiian Archipelago, J. Mar. Biol. (2011), http://dx.doi.org/10.1155/2011/460173.

[86] I.D. Williams, W.J. Walsh, J.T. Claisse, B.N. Tissot, K.A. Stamoulis, Impacts of a Hawaiian marine protected area network on the abundance and fishery sustainability of the yellow tang, Zebrasoma flavescens, Biol. Conserv. 142 (2009) 1066-1073, http://dx.doi.org/10.1016/j.biocon.2008.12.029.

[87] J.D. Bell, A. Cisneros-Montemayor, Q. Hanich, J.E. Johnson, P. Lehodey, B.R. Moore, M. Pratchett, G. Reygondeau, I. Senina, J. Virdin, C.C.C. Wabnitz, Adaptations to maintain the contributions of small-scale fisheries to food security in the Pacific Islands, Mar. Policy (2017), http://dx.doi.org/10.1016/j.marpol.2017.05.01.

[88] K.L. Oleson, K.A. Falinski, J. Lecky, C. Rowe, C.V. Kappel, K.A. Selkoe, C. White, Upstream solutions to coral reef conservation: the payoffs of smart and cooperative decision-making, J. Environ. Manag. 191 (2017) 8-18, http://dx.doi.org/10.1016/j.jenvman.2016.12.067. 
[89] T.J. Goreau, J.E. Smith, E.J. Conklin, C.M. Smith, C.L. Hunter, Fighting algae in Kaneohe Bay, Science 319 (2008) 157, http://dx.doi.org/10.1126/science.319.5860.

[90] J.N. Kittinger, T.M. Bambico, D. Minton, A. Miller, M. Mejia, N. Kalei, B. Wong, E.W. Glazier, Restoring ecosystems, restoring community: socioeconomic and cultural dimensions of a community-based coral reef restoration project, Reg. Environ. Change 16 (2016) 301-313 (Doi: 310.1007/s10113-10013-10572-x).

[91] M.A. MacNeil, N.A. Graham, J.E. Cinner, S.K. Wilson, I.D. Williams, J. Maina, S. Newman, A.M. Friedlander, S. Jupiter, N.V. Polunin, Recovery potential of the world's coral reef fishes, Nature 520 (2015) 341-344, http://dx.doi.org/10.1038/nature14358.

[92] P.A. Woodworth-Jefcoats, J.J. Polovina, J.C. Drazen, Climate change is projected to reduce carrying capacity and redistribute species richness in North Pacific pelagic marine ecosystems, Glob. Change Biol. 23 (2017) 1000-1008, http://dx.doi.org/10.1111/gcb.13471.

[93] L. Richmond, D. Kotowicz, J. Hospital, Monitoring socioeconomic impacts of Hawai'i's 2010 bigeye tuna closure: Complexities of local management in a global fishery, Ocean Coast. Manag. 106 (2015) 87-96, http://dx.doi.org/10.1016/j.ocecoaman.2015.01.015.

[94] C. Costello, S.D. Gaines, J. Lynham, Can catch shares prevent fisheries collapse? Science 321 (2008) 1678-1681, http://dx.doi.org/10.1126/science.1159478.

[95] M.C. Melnychuk, T.E. Essington, T.A. Branch, S.S. Heppell, O.P. Jensen, J.S. Link, J.S.D. Martell, A.M. Parma, J.G. Pope, A.D.M. Smith, Can catch share fisheries better track management targets? Fish. Fish. 13 (2012) 267-290, http://dx.doi.org/10.1111/j.1467-2979.2011.00429.x.

[96] M. Pan, Economic characteristics and management challenges of the Hawaii pelagic longline fisheries: will a catch share program help? Mar. Policy 44 (2014) 18-26, http://dx.doi.org/10.1016/j.marpol.2013.08.008.

[97] W.K. Kikuchi, Prehistoric Hawaiian fishponds, Science 193 (1976) 295-299, http://dx.doi.org/10.1126/science.193.4250.295.

[98] G. Keala, J.R. Hollyer, L. Castro, LOKO I'A: a Manual on Hawaiian Fishpond Restoration and Management, College of Tropical Agriculture and Human Resources, University of Hawai'i at Mānoa, Honolulu, 2007.

[99] L.E. Kam, P. Leung, A.C. Ostrowski, Economics of offshore aquaculture of Pacific threadfin (Polydactylus sexfilis) in Hawai'i, Aquaculture 223 (2003) 63-87, http://dx.doi.org/10.1016/S0044-8486(03)00162-5. 
[100] J.Q. Chen, M.C. Haws, Q.S.W. Fong, P. Leung, Economic feasibility of producing oysters using a small-scale Hawaiian fishpond model, Aquac. Rep. 5 (2017) 41-51, http://dx.doi.org/10.1016/j.aqrep.2016.12.001.

[101] T.K. Watson, M. Cain, S. Lemmo, L. Doktor, B. Asuncion, L. Mossman, J. Lyles, Farinbolt, J. Kittinger, Ho'ala Loko I'a: Permitting Application Guidebook, State of Hawaii Department of Land and Natural Resources, 2016 (online), 〈https://dlnr.hawaii.gov/occl/files/2016/08/Loko-laBook-FINAL-epub-single-080816.pdf). 